\title{
Hostilities resume over future of GM crops
}

David Adam, London

Like two punch-drunk boxers preparing for one last bout, the two sides in the British debate over genetically modified (GM) crops are getting ready to clamber back into the ring. A raft of consultation exercises and debates on the controversial technology have been launched in recent weeks, as industry groups and environmental activists prepare for the government decision on whether to allow commercial planting of the crops, which could be made next year.

The new efforts centre on a $£ 250,000$ (US\$390,000) scheme to foster debate on transgenic crops, paid for and promoted by the Department for Environment, Food and Rural Affairs. Those planning the exercise held their first meeting in London on 13 September. The debate's format has not been finalized, but one suggestion is to make and distribute a short film featuring the various viewpoints and to follow it up with a series of local discussion meetings. The results will be handed to the government next spring.

Lobby groups are already trading punches. On 17 September, the Soil Association, an organization that promotes organic farming, published a report suggesting that transgenic crops had cost the US economy $\$ 12$ billion since 1999 . The report cited a combination of low prices and falling exports to countries that are reluctant to buy food products containing GM ingredients. Product recalls, such as that required when a brand of taco shells was found to contain transgenic StarLink maize, which is intended for animal consumption only, also played a role. GM proponents then highlighted a report, issued in June by the National Center for Food and Agricultural Policy, a Washington-based independent thinktank, which claimed transgenic crops had increased US farm income by almost $\$ 1$ billion in 2001, thanks to greater yields and reduced herbicide use.

Attention will soon focus on scientific studies of the crops. The first data from fieldscale trials to assess the crops' impact on biodiversity are due early next year (see Nature 412, 760-763; 2001). But senior scientists say the studies are too limited to judge whether or not the new technology should be adopted. The trials do not address important aspects of the debate, including economic issues and the possible flow of transgenes into conventional crops.

The British government has ordered a review of issues such as gene flow and a study into the costs and benefits of GM crops. It has acknowledged that it is under pressure from US biotech companies to approve the crops, but has promised to consider the results of the new studies and the consultation exercise before making any decision.

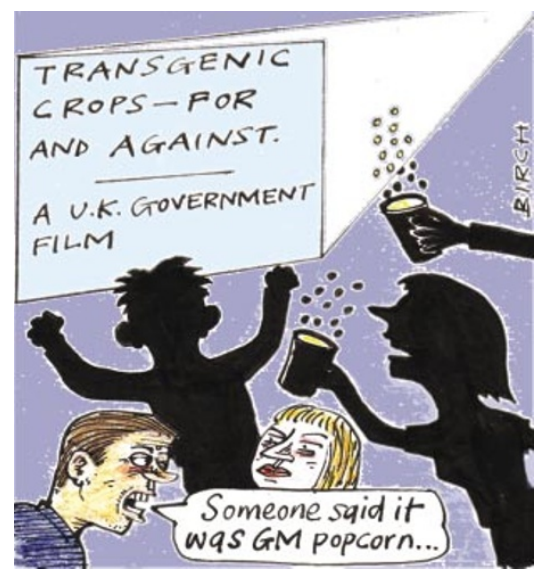

Passing economic and environmental tests may not be enough, however. The European Union is adamant that any food products containing transgenic ingredients should be clearly labelled as such, and this may deter consumers. Daniel Pearson, secretary of the Supply Chain Initiative on
Modified Agricultural Crops, a pro-GM industry group, says British farmers are interested in using the technology, but he admits that consumer reluctance could be a problem. "Clearly, farmers won't grow something they can't sell and you can't prejudge that they would find a market for it," he says.

The debate has also thrown up some unlikely alliances, not least that between the Natural Environment Research Council, Britain's main environmental research funding agency, and spiked, an online publication set up from the ashes of the now-defunct Living Marxism magazine. The council is sponsoring a debate about the field-scale trials on the spiked website - a decision that has already brought complaints from researchers.

"It is an unusual partnership," admits Marion O'Sullivan, a council spokeswoman. "But there's something about the GM debate that draws these comments. Nobody said anything when we sponsored one on climate change."

\section{Italy's space partners left in the dark}

Sally Goodman

The man at the head of Italy's national space agency, ASI, is ruffling feathers both at home and abroad.

Sergio Vetrella's plan for the agency's 2.8-million-euro (US\$2.8-million) budget for 2003-2005 leaves the future of many projects in doubt. The biggest single category in the budget for 2005 is "initiatives yet to be approved", leaving it unclear whether funding for other areas, including collaborations with NASA and the European Space Agency (ESA), remains intact.

The plan was approved by the Italian government on 5 August, but the details will not be finalized until the national budget is set later this year.

ASI's partners have already asked for clarification. David Southwood, director of ESA's science programme, says he is expecting an answer before his 15 October deadline about ASI's commitment to Venus Express, an exploratory mission to Venus planned for 2005 (see Nature 418, $360 ; 2002)$. "I will have little choice but to cancel the mission if they do not come on board," he says.

NASA is waiting to hear whether Italy will go ahead with building a water-seeking radar for the Mars Reconnaissance Orbiter, which is due to launch in 2005. "We will need a definite commitment from Italy within the next couple of months," says a NASA spokesman.

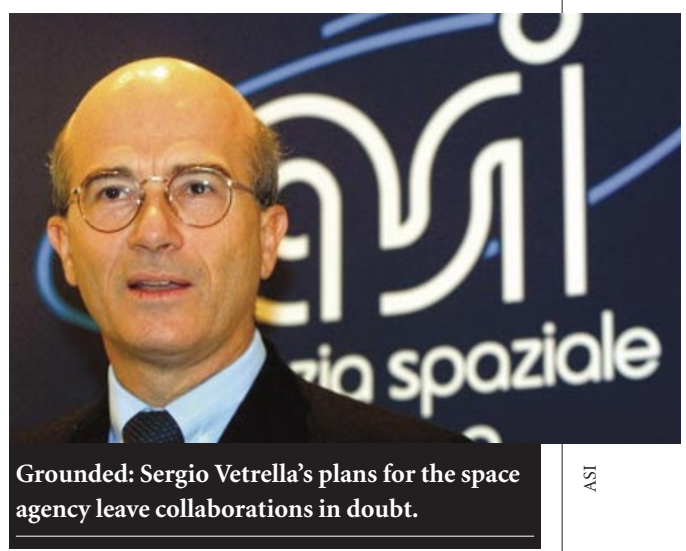

Vetrella, who was appointed last November, says that many project proposals were in a confused state with no clear written objectives when he arrived. "There was no time to include them in the defined part of the space plan. I preferred to separate them from the more mature projects," he says.

Southwood has also asked for assurances that the Italian instrument for Planck, ESA's 2007 mission to observe the cosmic microwave background, will be delivered on schedule. But he adds that Planck is suffering because other countries are also behind schedule for payload construction, and that in the future he wants member countries to make firmer commitments before industry is engaged. "There have been too many gentleman's agreements," says Southwood. 